\section{JURNAL ABDIMAS

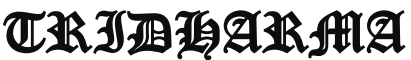

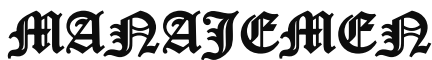

P-ISSN 2615-6849, E-ISSN 2622-3686

Jurnal ABDIMAS Vol. 2, No. 2, April 2021 Hal (54-60)

@Prodi Manajemen Fakultas Ekonomi Universitas Pamulang

Email: abdimasjurnal.unpam@gmail.com Telp: (021) 741-2566

\title{
EVALUASI PENERAPAN 3M DIMASA PANDEMIC COVID 19
}

\author{
Veta Lidya Delimah Pasaribu,Aulia Dwiyatni, Clara Sabina, \\ Mohamad Ridwan, Deril Dwi Gunawan, Bunga Cahya Noviani \\ Dosen Dan Mahasiswa Prodi Manajemen Fakultas Ekonomi \\ Universitas Pamulang \\ Email : Veta01889@unpam.ac.id, auliadwie30@gmail.com, \\ clarasabina6@gmail.com, mridwan20655@gmail.com, \\ derildwigunawan@gmail.com, bungacahyanoviani@gmail.com
}

\begin{abstract}
ABSTRAK
Tujuan dari kegiatan Pengabdian Kepada Masyarakat ini adalah untuk melaksanakan salah satu kegiatan PKM. Selain itu, melalui kegiatan Pengabdian Kepada Masyarakat ini mahasiswa diharapkan dapat memberikan kontribusi besar kepada pengembangan dan penerapan keilmuan dalam masyarakat.

Metode kegiatan yang digunakan adalah tim pelaksana mengunjungi PT. Abisatya panca nawa Kelurahan Pamulang barat Kota Tangerang Selatan dan memberikan penyuluhan tanggal 11 Maret 2021. Kegiatan pengabdian dilakukan dengan cara memberikan penyuluhan mengenai apa yang perlu diperhatikan dalam menghadapi wabah covid 19 diantaranya memperhatikan kesehatan rohani, cara pola pikir, memilah informasi yang didapat dan dengan memberikan edukasi tentang motivasi.

Masa pandemi covid-19 seperti ini, sangat mudah untuk mengalami kesulitan untuk mendapatkan motivasi. Di tengah situasi yang serba tidak pasti seperti sekarang ini orang-orang bisa dengan mudah mengalami putus asa yang tentunya hal ini juga bisa menyebabkan stres yang meningkat. Dengan memberikan penyuluhan, maka PT. Abisatya panca nawa memperoleh berbagai macam informasi dan strategi-strategi mengenai bagaimana untuk tetap produktif selama menghadapi wabah covid 19.
\end{abstract}

\section{Kata kunci : Motivasi, Pandemic Era}

\section{ABSTRACT}

The purpose of this Community Service activity is to carry out one of the Tri Dharma of Higher Education. In addition, through this Community Service activity students are expected to make a major contribution to the development and application of science in the community.

The method of activity used is the implementation team visited PT. Abisatya panca nawa Tanggerang Selatan Pamulang Village west of South Tangerang City and provided counseling on March 21, 2021. Devotional activities are carried out by providing counseling on what needs to be considered in the face of the covid 19 outbreak including paying attention to spiritual health, mindset, sorting out the information obtained and by providing education about motivation. 


\section{JURNAL ABDIMAS

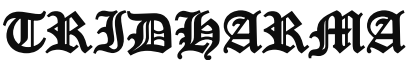

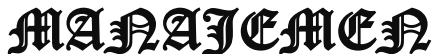

P-ISSN 2615-6849, E-ISSN 2622-3686

Jurnal ABDIMAS Vol. 2, No. 2, April 2021 Hal (54-60)

@Prodi Manajemen Fakultas Ekonomi Universitas Pamulang

Email: abdimasjurnal.unpam@gmail.com Telp: (021) 741-2566

During the covid-19 pandemic like this, it is very easy to have difficulty getting motivated. In the midst of such an uncertain situation today people can easily experience despair which of course this can also lead to increased stress. By providing counseling, PT. Abisatya panca nawa obtained a variety of information and strategies on how to stay productive during the covid 19 outbreak.

Keywords: Motivation, Pandemic Era

\section{PENDAHULUAN}

Penyebaran virus corona jenis baru (SARS-Cov-2) di penghujung tahun 2019 yang kemudian diberi nama Covid -19 sangat menjadi perhatian dan kekhawatiran dunia. Covid-19 pertama kali ditemukan di kota Wuhan China yang kemudia bermigrasi dan mewabah ke seluruh dunia. Akibat dari penyebarannya yang cukup masiv tersebut pada akhirnya pada tanggal 11 Maret 2020 organisasi kesehatan dunia World Health

Organizatin (WHO) penyebacaran Covid 19 pandemi.

Setelah menetapkan
sebagai

ditetapkannya pandemi Covid-19, tentu saja berbagai negara yang belum maupun yang telah terpapar Covid-19 harus melakukan berbagai upaya untuk menghentikannya. Dilansir dari healthline, direktur jendral WHO, Tedros Ghebreyesus menetapkan 4 (empat) hal utama yang harus dilakukan oleh suatu negara dalam menghadapi penularan Covid-19, yaitu; mempersiapkan dan bersiap, b) deteksi, lindungi, dan rawat, c) kurangi penyebaran, d) inovasi dan belajar

\begin{tabular}{lrr}
\multicolumn{1}{c}{ World } & Health \\
Organizatin (WHO) & juga \\
mengungkapkan & bahwa & cara \\
penyebaran Covid-19 & melalui tetesan \\
kecil air liur yang keluar dari hidung \\
atau mulut ketika orang yang
\end{tabular}

terinfeksi Covid-19 bersin atau batuk. Tetesan itu kemudian mendarat di sebuah benda atau permukaan yang disentuh orang sehat. Juga bisa menyebar ketika dihirup langsung oleh orang yang sehat ketika mereka berdekatan. Itu sebabnya penting untuk menjaga jarak satu meter lebih dari orang yang sakit.

Kepatuhan terhadap $3 M$ (Mencuci tangan, Memakai masker, dan Menjaga jarak) mutlak menjadi prasyarat memutus rantai penularan Covid-19. Data kasus terkonfirmasi Covid19 khususnya di wilayah Kota Tegal per 5 Oktober 2020 mencapai 196 warga, dengan rincian 10 orang dirawat, 51 orang jalani isolasi mandiri, 120 sembuh dan 15 orang meninggal dunia. Sebaran yang terpapar Covid-19 per kelurahan yang mendominasi adalah Kelurahan Mintaragen Kecamatan Tegal Timur Kota Tegal dikarenakan wilayah penduduknya yang padat mencapai 16.846 jiwa dengan luas wilayah hanya $14,2 \mathrm{~km}$ dan juga merupakan wilayah dekat pantai, dimana banyak penduduknya mengabaikan protokol kesehatan.

Maka dari itu, sosialisasi kepada masyarakat di Kelurahan Mintaragen ini untuk lebih menyadarkan masyarakat akan perlunya kehidupan normal baru (new normal) melalui kegiatan Kuliah Kerja Nyata Tematik. Metode pelaksanaan dilakukan dengan soft program dan hard program. Soft 


\section{JURNAL ABDIMAS

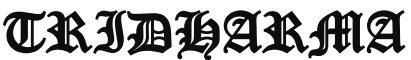

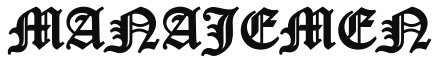

P-ISSN 2615-6849, E-ISSN 2622-3686

Jurnal ABDIMAS Vol. 2, No. 2, April 2021 Hal (54-60)

@ Prodi Manajemen Fakultas Ekonomi Universitas Pamulang

Email: abdimasjurnal.unpam@gmail.com Telp: (021) 741-2566 program meliputi kegiatan sosialisasi dan hard program meliputi kegiatan fisik pencegahan dan penularan Virus Covid-19. Hasil kegiatan menunjukkan peningkatan pemahaman masyarakat di Kelurahan Mintaragen terhadap perubahan perilaku di era normal baru dan penurunan angka terpapar covid-19 dan meninggal dunia disertai kenaikan angka kesembuhan dan perwujudan Kelurahan Mintaragen menjadi Kelurahan Siaga Covid-19

Maka dari itu, sosialisasi terhadap masyarakat ini menjadi penting untuk lebih menyadarkan masyarakat akan perlunya kehidupan normal baru (new normal) dimana salah satu nya adalah merubah perilaku bermasyarakat ditengah pandemik Covid-19 melalui kegiatan Kuliah Kerja Nyata $(\mathrm{KKN})$

\section{RUMUSAN MASALAH}

Berdasarkan uraian pada bagian latar belakang di atas maka yang menjadi rumusan masalah penelitian ini adalah sebagai berikut:
a. Bagaimanakah pencegahan penularan Covid-19 ?
b. Bagaimanakah Evaluasi penerapan 3M dimasa pandemic Covid-19?

\section{TUJUAN KEGIATAN}

Kegiatan pelatihan ini diharapkan mampu memberikan dampak jangka panjang bagi lingkungan sekitar.

a. Memberikan pengetahuan kepada PT. Abisatya panca nawa bagaimana bisa membangun motivasi dan harapan khususnya di masa-masa sulit seperti sekarang ini dengan cara harus mengubah pola pikir subyektif agar menjadi pribadi terbuka, Menerima perbedaan, Toleransi dan dapat berbaur, dan Bersosialisasi dalam lingkungannya.

b. Memberikan pengetahuan kepada PT. Abisatya panca nawa serta menjaga semangat kebersamaan dan gotong-royong sebagai jatidiri bangsa Indonesia.

c. Memotivasi berbagai inisiatif di tengah masyarakat untuk saling mendukung satu sama lain melewati masa-masa sulit ini.

\section{TINJAUAN PUSTAKA \\ Faktor-faktor Yang Mempengaruhi Motivasi}

Motivasi sebagai proses batin atau proses psikologis dalam diri seseorang, sangat dipengaruhi oleh beberapa faktor. Faktor-faktor tersebut antara lain :

1. Faktor Intern (Internal) berasal dari dalam diri individu

- Pembawaan individu

- Tingkat pendidikan

- Pengalaman masa lampau

- Keinginan atau harapan masa depan.

Persepsi individu mengenai diri sendiri; seseorang termotivasi atau tidak untuk melakukan sesuatu banyak tergantung pada proses kognitif berupa persepsi. Persepsi seseorang tentang dirinya sendiri akan mendorong dan mengarahkan perilaku seseorang untuk bertindak;

Harga diri dan prestasi; faktor ini mendorong atau mengarahkan inidvidu (memotivasi) untuk berusaha agar menjadi pribadi yang mandiri, kuat, dan memperoleh kebebasan serta 


\section{JURNAL ABDIMAS

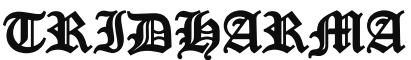

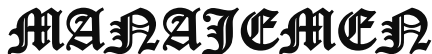

P-ISSN 2615-6849, E-ISSN 2622-3686

Jurnal ABDIMAS Vol. 2, No. 2, April 2021 Hal (54-60)

@Prodi Manajemen Fakultas Ekonomi Universitas Pamulang

Email: abdimasjurnal.unpam@ gmail.com Telp: (021) 741-2566 mendapatkan status tertentu dalam lingkungan masyarakat; serta dapat mendorong individu untuk berprestasi;

Adanya harapan-harapan akan masa depan. Harapan ini merupakan informasi objektif dari lingkungan yang mempengaruhi sikap dan perasaan subjektif seseorang. Harapan merupakan tujuan dari perilaku.

Kebutuhan; manusia dimotivasi oleh kebutuhan untuk menjadikan dirinya sendiri yang berfungsi secara penuh, sehingga mampu meraih potensinya secara total. Kebutuhan akan mendorong dan mengarahkan seseorang untuk mencari atau menghindari, mengarahkan dan memberi respon terhadap tekanan yang dialaminya.

Sumber lain mengungkapkan, bahwa didalam motivasi itu terdapat suatu rangkaian interaksi antar berbagai faktor. Berbagai faktor yang dimaksud meliputi :

1. Individu dengan segala unsurunsurnya : kemampuan dan ketrampilan, kebiasaan, sikap dan sistem nilai yang dianut, pengalaman traumatis, latar belakang kehidupan sosial budaya, tingkat kedewasaan, dsb.

2. Proses penyesuaian yang harus dilakukan oleh masing-masing individu terhadap aktifitas.

3. Reaksi yang timbul terhadap pengaruh individu

4. Perilaku atas perbuatan yang ditampilkan oleh individu

5. Timbulnya persepsi dan bangkitnya kebutuhan baru, citacita dan tujuan

\section{Pentingnya Motivasi \\ Mengubah pola pikir yang subyektif mencakup tiga hal, diantaranya:}

- Keseimbangan antara melakukan hal-hal besar dan hal-hal yang sepele

- Mengubah pola pikir dari memenuhi kebutuhan diri sendiri menjadi memenuhi kebutuhan orang lain

- Dan fokus pada pelaksanaan tanggung jawab.

\section{Manfaat Motivasi}

Manfaat evaluasi penerapan $3 M$ dimasa pandemic covid 19 sebagai berikut:

1. Menimbulkan rasa syukur

Ketika melihat lingkungan sekitar, akan menjadi pribadi yang lebih bersyukur terhadap apa yang dimiliki saat ini.

2. Meningkatkan kepercayaan dalam motivasi

Cukup banyak manfaat yang diberikan dari berbagi dengan sesama, salah satunya adalah akan semakin dihargai dan dihormati oleh sekeliling. dapat menanamkan rasa percaya diri dan motivasi terhadap mereka bahwa segala peristiwa yang terjadi saat ini akan memberikan hadiah yang lebih baik di hari yang akan datang.

3. Memberikan harapan baru

Tolong-menolong mampu meningkatkan rasa kepedulian terhadap kondisi sosial dan mereka yang membutuhkan.

4. Menciptakan tali persaudaraan Akan lebih terbuka untuk saling berangkulan dan bersatu.

5. Menularkan orang lain untuk berbuat kebaikan

Membantu mereka yang membutuhkan. Ketika membantu mereka yang membutuhkan pertolongan, maka perbuatan tersebut akan diingat oleh mereka. 


\section{JURNAL ABDIMAS

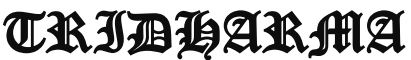

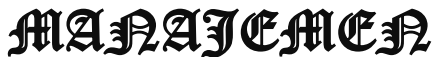

P-ISSN 2615-6849, E-ISSN 2622-3686

Jurnal ABDIMAS Vol. 2, No. 2, April 2021 Hal (54-60)

@Prodi Manajemen Fakultas Ekonomi Universitas Pamulang

Email: abdimasjurnal.unpam@ gmail.com Telp: (021) 741-2566

\section{METODE PELAKSANAAN}

Pelaksanaan program
pengabdian pada masyarakat
terintegrasi PKM ini dilaksanakan
sebagai upaya peningkatan kesadaran
masyarakat di Tanggerang Selatan
khususnya PT. Abisatya panca nawa
agar masyarakat lebih waspada dan
tetap menjaga kesehatannya selama
masa pandemik ini. Melalui kegiatan
pengabdian pada masyarakat ini akan
itawarkan berbagai solusi bagi
permasalahan - permasalahan yang
telah dirumuskan di atas. Langkah -
langkah pendekatan yang digunakan
yakni sebagai berikut: 1) Tahap
Perencanaan; 2) Tahap Persiapan; 3)
Tahap Pelaksanaan; 4) Tahap Evaluasi.
Apabila kita menginginkan hasil yang
bermakna maka pengabdian ini perlu
direncanakan dengan sebaik-baiknya,
dengan matang. Berikut merupakan
penjelasan dari setiap Langkah yang
dilakukan:

\section{Tahap Perencanaan}

Tahapan awal ini merupakan penyusunan rencana yang dilakukan, dan juga mengatur rencana terkait jobdesk. Kemudian untuk pembagian tugas tetap berjalan dengan baik meskipun lebih banyak mengerjakannya jarak jauh.

\section{Tahap Persiapan}

Pada tahap ini dilakukan penyiapan pelaksana dan penyiapan lapangan. Pada tahap persiapan pelaksana, tim mempersiapkan tenaga pelaksana dan pendukung yang dapat dilakukan oleh bagian dari masyarakat itu sendiri. Selanjutnya, pada tahap persiapan lapangan, diawali dengan melakukan studi kelayakan terhadap kelurahan yang akan dijadikan sasaran dilakukan secara formal ataupun informal.

\section{Tahap Pelaksanaan}

Tahap ini merupakan salah satu tahap paling penting dalam proses pengabdian kepada masyarakat. Peran dosen sebagai sasaran program diharapkan dapat menjaga keberlangsungan program yang telah dikembangkan.

\section{Tahap Evaluasi}

Evaluasi sebagai proses pengawasan dari pelaksana terhadap program pengabdian kepada masyarakat yang sedang berjalan dilakukan dengan melibatkan warga. Evaluasi dilaksanakan dengan melihat respon serta insight yang diberikan oleh masyarakat terkait COVID-19. Semua metode tersebut merupakan satu kesatuan dari program Pengabdian Kepada Masyarakat in

\section{HASIL DAN PEMBAHASAN Hasil Kegiatan}

Formula paling efektif memutus mata rantai penyebaran virus corona saat ini adalah penerapan $3 \mathrm{M}$ yakni memakai masker, menjaga jarak, dan rajin mencuci tangan.

Dilapangan, Penerapan protokol kesehatan masih belum maksimal meski angka penyebaran Covid-19 terus naik,

Karena itu, sinergitas lintas sektor untuk memperluas informasi dan edukasi terkait protokol kesehatan, termasuk dengan pelaku dunia usaha, filantropi, hingga media perlu dilakukan secara terpadu. Melalui kemitraan berbagai pihak, perluasan informasi untuk bisa menerapkan protokol kesehatan bisa diperkuat.

Penerapan $3 \mathrm{M}$ berfungsi preventif antisipatif, semakin banyak masyarakat yang disiplin menerapkannya, maka ikhtiar 


\section{JURNAL ABDIMAS

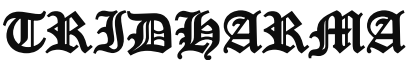

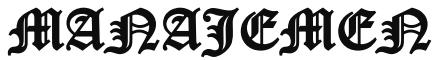

P-ISSN 2615-6849, E-ISSN 2622-3686

Jurnal ABDIMAS Vol. 2, No. 2, April 2021 Hal (54-60)

@Prodi Manajemen Fakultas Ekonomi Universitas Pamulang

Email: abdimasjurnal.unpam@ gmail.com Telp: (021) 741-2566 pencegahan penularan Covid 19 akan semakin maksimal.

Relevan dengn pepatah "Mencegah lebih baik daripada mengobati". Pepatah ini agaknya penting kita lakukan di masa pandemi COVID-19 ini. Tak perlu biaya mahal untuk pencegahan penyebaran virus Corona lakukan 3M dan jalankan protokol kesehatan dengan disiplin. Jika sudah divonis positif COVID-19, tidak hanya berdampak pada kesehatan dan psikologi, tapi juga kerugian ekonomi

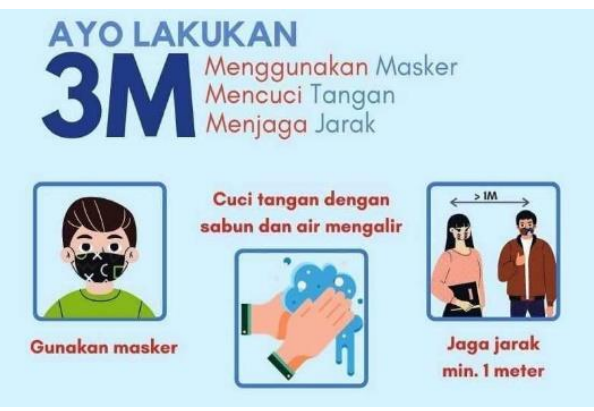

\section{Pembahasan}

Kegiatan Pengabdian ini dilakukan di mengunjungi PT. Abisatya panca nawa Kelurahan Pamulang barat Kota Tangerang Selatan. Tema yang diambil adalah Evaluausi Penerapan $3 M$ dimasa pandemic covid 19. Selama pelaksanaan kegiatan, peserta antusias mengikuti karena ini hal yang masih baru bagi mereka. Ketertarikan mereka dikuatkan dengan adanya partisipasi aktif baik, baik memberikan jawaban dan tanggapan dari moderator dan pemateri, maupun memberi pertanyaan kepada moderator dan pemateri. Kegiatan berlangsung dengan tertib dan lancar karena mengunjungi PT. Abisatya panca nawa Kelurahan Pamulang barat Kota Tangerang Selatan sangat mendukung kegiatan ini dengan membantu menyiapkan tempat dan mengkondisikan agar siap mengikuti kegiatan ini

\section{KESIMPULAN DAN SARAN Kesimpulan}

Kegiatan pengabdian kepada masyarakat tentang Protokol Kesehatan Covid-19 dilakukan sebagai salah satu Upaya Pencegahan Covid-19 di area PT. Abisatya panca nawa Tanggerang Selatan. Hasil kegiatan ini menunjukkan adanya peningkatan pengetahuan dan kepatuhan peserta dalam menerapkan protokol kesehatan Covid-19. TIM pengabdian berasumsi bahwa pemberian informasi tentang Covid-19 dengan sasaran kelompok efektif dilakukan.

\section{Saran}

Diharapkan masyarakat dapat menyadari bahwa penerapan perilaku $3 \mathrm{M}$ tersebut sangat penting untuk pencegahan COVID 19. Selain itu masyarakat dapat secara aktif mencari tahu dan menambah ilmu pengetahuan mengenai perilaku 3M. Sudah saatnya masyarakat dapat menerima pengetahuan pengetahuan baru yang berguna bagi diri sendiri dan kesehatannya.

Sikap masyarakat juga harus lebih terbuka terhadap pengetahuan tentang perilaku $3 \mathrm{M}$ agar pelaksanaan $3 \mathrm{M}$ bisa lebih maksimal karena dengan menerapkan perilaku 3M ini masyarakat dapat terhindar dari Covid 19. diharapkan masyarakat bisa menjadi terbiasa menerapkan perilaku $3 \mathrm{M}$ sehari hari.

\section{DAFTAR PUSTAKA}




\section{JURNAL ABDIMAS

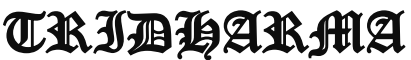

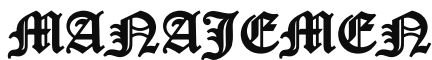

P-ISSN 2615-6849, E-ISSN 2622-3686

Jurnal ABDIMAS Vol. 2, No. 2, April 2021 Hal (54-60)

@ Prodi Manajemen Fakultas Ekonomi Universitas Pamulang

Email: abdimasjurnal.unpam@ gmail.com Telp: (021) 741-2566
Anismadiyah, V., Febriana, H., Irnawati, J, Rismanty, F.A., Suryanto,W. (2021)

Financial Planning For Millenials In Pandemic Era Vol. 2, Universitas Pamulang

Pasaribu, V. L. D., Susanti, F., \& Hartuti, E. T. K. (2019). Memotivasi Siswa dan Siswi SMK Letris Indonesia di Dalam Menentukan Pilihan Untuk Melanjutkan Pendidikan Atau Bekerja Setelah Lulus Sekolah. Jurnal Pengabdian Dharma Laksana, 1(2), 161-172.

Pasaribu, V. L. D., Agrasadya, A., Shabrina, N., \& Krisnaldy, K. (2020). MENJADI ENTERPRENEUR MUDA YANG MEMILIKI JIWA LEADERSHIP UNTUK MENGHADAPI MASA DEPAN. $A b d i$ Laksana, 1(1).

Pasaribu, V. L. D., Elburdah, R. P., Sudarso, E., \& Fauziah, G. (2020). PENGGUNAAN MANAJEMEN WAKTU TERHADAP PENINGKATAN PRESTASI BELAJAR DI SMP ARAISIYAH. Jurnal ABDIMAS Tri Dharma Manajemen, l(1).

Pasaribu, V. L. D., Sulaiman, S., Sutiman, S., Thaharudin, T., \& Purnomo, B. Y. (2020). PENGENALAN LETAK POSYANDU TERDEKAT DIKELURAHAN PISANGAN DENGAN MANAJEMEN PEMASARAN REVOLUSI 4.0 UNTUK MENINGKATKAN PENGETAHUAN MASYARAKAT LETAK DAN FUNGSI POSYANDU TERDEKAT PADA KELURAHAN PISANGAN. DEDIKASI PKM, 1 (1), 105-110.

Pasaribu, V. L. D., Oktrima, B., Prabowo, B., Arianto, N., \& Haryoko, U. B. (2020). PROGAM PENDAMPINGAN DAN PENYELENGGARAAN PENDIDIKAN ANAK PADA USIA DINI TERHADAP PRESTASI BELAJAR DILINGKUNGAN RT 020 RW 009. KEL GIRI PENI. KEC WATES. YOGYAKARTA. JURNAL LOKABMAS KREATIF, 1(1), 71-75.
Surahman, A., Wartono,T., Setyawati, L., Kristianti, Putri, L.L., Laksamana, H., Nuraldy.(2020) Menumbuhkan Motivasi Bekerja dan Cara Mengatur Keuangan Selama Masa PSBB COVID 19 Vol. 1 Universitas Pamulang.

https://www.allianz.co.id/explore/detail /manfaat-berbagi-dengansesama-di-tengah-pandemicovid-19/100865

https://www.medcom.id/rona/kesehatan /8KyX146k-pentingnyamempertahankan-motivasi-ditengah-pandemi-covid-19

http://new.widyamataram.ac.id/content/ news/meningkatkan-jiwanasionalisme-untuk-hadapitantangan-pandemi-covid19\#.YD5wz28zbIU

\section{FOTO DOKUMENTASI}
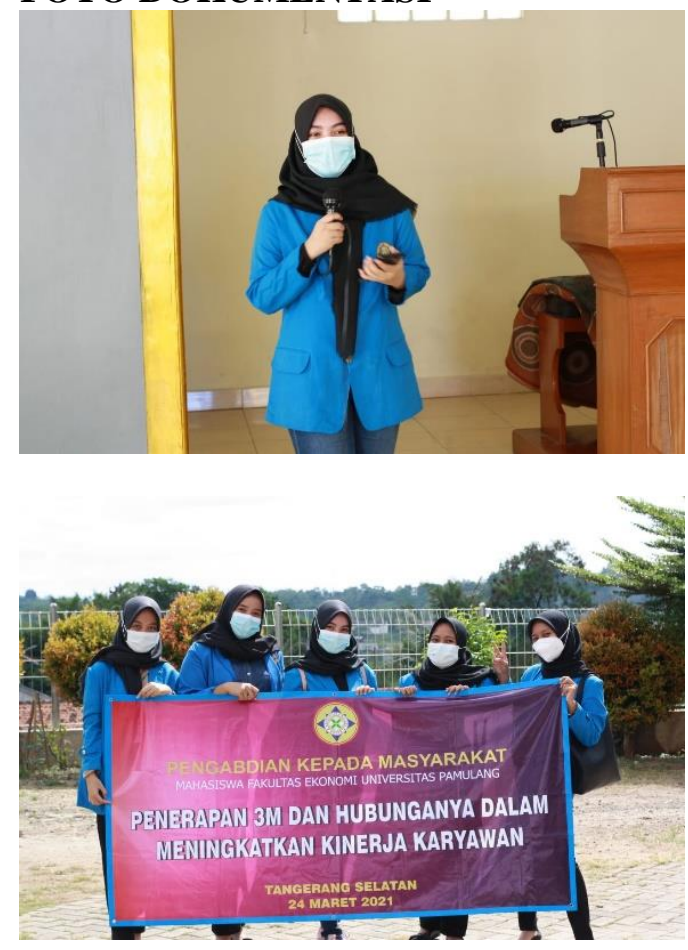